\title{
MIGRATION AND LEGAL PRECARITY IN THE TIME OF PANDEMIC: QUALITATIVE RESEARCH ON THE ITALIAN CASE
}

\author{
Paola BONIZZONI', Senyo DOTSEY"
}

COBISS 1.01

\section{ABSTRACT \\ Migration and Legal Precarity in the Time of Pandemic: \\ Qualitative Research on the Italian Case}

The COVID-19 pandemic has unequally impacted the lives of Italian subjects. The article uses evidence from forty-seven semi-structured interviews with various migrant groups to illuminate how temporalities embedded in Italy's migration governance shape migrants' precarious legal status and access to welfare. The authors show that whereas migrants with secure legal status or citizenship have not engaged significantly with Italian bureaucracies, they have no easy access to welfare as it is contingent on their employment and financial status. Migrants with precarious status have been the worst hit by the pandemic's secondary effects across several fronts. These findings have implications for policy and future research.

KEYWORDS: COVID-19, legal precarity, migration, temporality, welfare services, Italy

\section{IZVLEČEK}

Migracije in pravna negotovost med pandemijo:

Kvalitativna študija italijanskega primera

Pandemija Covida-19 je neenakopravno posegla v življenja prebivalcev Italije. Članek temelji na podatkih iz 47 polstrukturiranih intervjujev z različnimi skupinami migrantov. Ti kažejo, kako začasne rešitve, vgrajene v italijanski sistem upravljanja migracij, vplivajo tako na negotovi pravni status migrantov kot na njihov dostop do socialnega varstva. Čeprav migranti z urejenim pravnim statusom ali državljanstvom nimajo veliko opravka z italijansko birokracijo, kljub temu nimajo lahkega dostopa do socialne blaginje, ki je odvisna od njihovega delovnega in finančnega statusa. Migrante prekarce so najbolj prizadeli sekundarni učinki pandemije. Ugotovitve avtorjev so pomembne tako za politiko upravljanja migracij kot za prihodnje raziskave.

KLJUČNE BESEDE: Covid-19, pravna negotovost, migracije, začasnost, socialno skrbstvo, Italija

Assoc. professor of sociology, Department of Social and Political Sciences, University of Milan, Italy; paola.bonizzoni@unimi.it, https://orcid.org/0000-0001-6849-7568.

\| Research fellow, Department of Social and Political Sciences, University of Milan, Italy; senyo. dotsey@unimi.it, https://orcid.org/0000-0002-2164-1734. 


\section{INTRODUCTION: MIGRATION, TEMPORALITY, AND LEGAL PRECARITY ${ }^{1}$}

The COVID-19 pandemic has affected all segments of the population around the world, albeit in varying degrees. In this respect, migrant populations are especially "vulnerable to the direct and indirect impacts of Covid-19" (Guadagno 2020: 4) due to the multiple forms of vulnerability, risk, and precarity that they share with other marginalized social groups. In this article, we investigate the potential impact of the pandemic on migrants' (il)legal status in the host countries.

In Europe, like elsewhere, the pandemic has led to the closure of international borders, making cross-border mobility difficult. Further, it "has impacted procedures to apply for and obtain residence and work permits, as government offices have reduced their services or closed during this time," ${ }^{2}$ leading to the closure and/ or virtualization of administrative offices and government agencies that process applications and issue residence and work permits and naturalizations to foreign nationals. This, combined with the effects of the economic crisis triggered by the pandemic, has jeopardized, as we shall discuss, the issuance or renewal of temporary employment-based residence permits, as well as the acquisition of the material integration requirements attached to family reunification, long-term residence, or naturalization procedures.

Legal status considerably shapes several aspects of a (forced) migrant's life, from access to the labor market, education, health, and housing, to future full citizenship status aspirations (Da Lomba 2010). While the pandemic has affected citizens and denizens alike, the peculiar legal standing of migrants and, more specifically, the kind of residence permit they do (not) possess might, in critical ways, heavily affect their access to the labor market and social rights and protections, bearing especially critical consequences in a time of crisis (Dotsey 2018; Devillanova et al. 2020). While the possession of a more or less stable and secure legal status does not automatically guarantee full social inclusion (Standing 2011; Dotsey 2018), precariousness experienced in one's legal status might (be) exacerbate(d) or trigger(ed) (by) precariousness in other spheres and conditions (Banki 2013).

Temporality is a critical dimension in the analysis of both migration governance and a migrant's experiences, a feature that is, however, sometimes missing in scholarly debates (Cwerner 2001). This study draws attention to how temporalities embedded in migration governance might affect migrants' experiences in times of the COVID-19 pandemic in Italy, one of the hardest-hit countries in Europe.

Italian immigration policies are well-known for creating a stratified system of multiple legal statuses characterized by blurred and differentiated rights (Bonizzoni 2020). The prolonged legal uncertainty and waiting periods, as well as bureaucratic

1 This article is part of the output of the project "De-bordering activities and citizenship from below of asylum seekers in Italy. Policies, practices, people (ASIT)" (PRIN 2017).

2 See https://ec.europa.eu/migrant-integration/news/covid-19s-impact-on-migrant-communities-20 (19 Feb. 2021). 
complexities involved in obtaining and renewing residence permits, often lead migrants to experience extended forms of legal precarity, resulting in "institutional irregularity" (Ferraris 2008) and in limbo status.

In this article, we draw on different migrant groups (including naturalized and settled, temporary economic migrants, asylum-seekers, irregular migrants, refugees, and humanitarian migrants) who have been living in Italy for as many as months to decades. The term migrants encompasses all groups unless otherwise specified or stated individually to show comparison, emphasis, and/or distinction. The interviews collected show how differently-precarious legal conditions embedded in the Italian immigration system have interacted with the COVID-19 crisis to produce specific outcomes.

The article proceeds as follows. We provide an overview of temporal migration governance and precarious socio-legal status production in Italy and how this might shape access to welfare services in light of the pandemic. Section 3 provides the research context and methodology, while the main empirical findings and analysis appear in section 4 . The final section offers some concluding thoughts.

\section{TEMPORALITIES, THE STATE, AND MIGRATION GOVERNANCE: INSIGHTS FROM ITALY}

Migrants are often neither citizens nor permanent residents (Dotsey, LumleySapanski 2021). Except for migrants with full citizenship status who thus somewhat enjoy all formal rights and privileges accrued to native citizens, all other migrant groups are denizens, with these different groups having access only to some or no rights (Standing 2011).

States employ temporal "devices and rationalities" (Anderson 2010b) to govern immigration flows. Time and temporality are used to define the boundaries of state membership, for instance, through the use of qualification times (Anderson 2010b), in determining how long one must be present to be eligible for citizenship, longterm residency, or family reunification.

Speeding or elongating asylum or status processing times (Cwerner 2004) and/or the duration of residence permits, creating new forms of ongoing and permanently unresolved migration statuses (see Simmelink 2011; Baas, Yeoh 2019) are concrete examples of temporal bordering techniques (that complement the more studied spatial ones, such as the use of undefined spatial confinement) in defining, selecting and deterring migrants.

The administrative regulation of a migrant's status also intersects in complex ways with welfare arrangements, as states may use temporalities to regulate access to certain rights or benefits. For instance, migrants may be asked to demonstrate continuous presence within a receiving location to qualify for public benefits (Anderson 2010b; Gargiulo 2017). 
Individuals who are awaiting the processing of their migration claims are often unable to fully participate in activities such as work and school (Hartley et al. 2017), leading to the experience of a condition of liminality. Exposed to temporal, uncertain, and precarious circumstances, including frequent and unpredictable changes in labor and immigration laws, migrants with a precarious legal status often lack the opportunity for long-term integration and social advancement plans in the host society (Anderson 2010a).

Different types of visa and residence permits regulate the entry and stay of foreign nationals in Italy, mainly depending on their mode and reasons of entry and stay (e.g., humanitarian migrants, family reunifications, students, etc.).

As regards economic migrants, the Legislative Decree $286 / 1998$ closely ties migration status to employment status, implying that, on the one hand, economic migrants should already have a contract when entering Italy through an employment visa and that, on the other hand, they can easily lapse into illegality as a result of job loss (Dell'Olio 2004). Concerning family reunification, their status is tied to and dependent upon that of the sponsor, who should demonstrate the possession of adequate housing and income, proportional to the number of persons composing the family.

Within the context of forced migrants, Italy distinguishes different forms of national and international protection, each characterized by different rights. For instance, Geneva-status holders, compared to those entitled to subsidiary protection and the newly-introduced special cases residence permit, enjoy a longer residence permit, leading to privileged naturalization and naturalization routes.

In the case of temporary residence permits, eligibility must be repeatedly proven, and evaluations are characterized by a certain degree of administrative discretion and arbitrariness because immigration directives and amendments lack transparency and consistency and are full of lacunae (Veugelers 1994).

The main paths to legal stabilization in Italy are offered by the European Commission Long-Term Residence Permit (Soggiorno per Soggiornanti di Lungo Periodo SLP) and by naturalization provisions. The SLP may be acquired by immigrants or nonEU nationals who have been legally residing in Italy for at least five years after meeting specific integration requirements (that is, knowledge of the Italian language, sufficient income, and, in the case of dependent relatives, adequate housing conditions).

As regards naturalization, there are three primary ways of gaining Italian citizenship: through descendants (jure sanguinis), marriage to an Italian citizen, and residence (ius domicilii). In the latter case, a non-EU citizen may apply if s/he has resided without interruption in Italy for ten years, along with showing a sufficient level of income, proportional to the number of the dependent family members (Dotsey 2018).

Italian immigration laws, anchored by temporary and contingent permit systems, have traditionally contributed to a situation of "institutionalized irregularity" (Calavita 2005) that recent policy reforms have further increased. The so-called 
Salvini Decree ${ }^{3}$ has, in this respect, further increased the condition of precarity and uncertainty deriving from migrants' legal status; the law abolished the humanitarian protection status, replacing it with a special case permit, which is awarded only in a limited set of circumstances. That represented a significant blow to asylum-seekers, as most of them have been entitled to a humanitarian status.

It is in this context that the effects of the COVID-19 pandemic have played out.

The pandemic has led to the closure, contingent opening, and/or virtualization of the main public administrations (e.g., municipalities, police headquarters, consulates, territorial commissions, etc.) and support services (e.g., associations, churches, trade unions), bearing a potentially relevant impact on those waiting for a decision regarding one's status.

As part of the measures to contain the onslaught of the pandemic, the government enacted a decree March 2020, no. 18 (Decreto Cura Italia) converted into law no. $27 / 2020$. Among other things, the government temporarily extended the validity of expiring residence permits through a series of repeated, short-term, statusextension measures. While this has temporarily provided migrants with some sort of mental tranquility, it has also put migrants' legal life on hold, expanding a grey area of an in-limbo status - not expired but not renewed - prolonging uncertainty in a time of worsening economic conditions.

Further, the government had granted a selective amnesty, targeted to key economic sectors such as the agricultural sector (e.g., livestock and fisheries) and the home care sectors (e.g., home care providers and domestic work). It is, however, noteworthy that a large part of the research was done before the regularization process started.

As regards welfare support, the government has provided emergency measures to those who found themselves especially hit by the economic effect of the pandemic. However, as we shall see, the legal barriers, informational uncertainty, and economic and bureaucratic requirements for receiving these welfare support packages prevented several migrants from applying.

\section{METHODOLOGY}

This study was conducted during the first phase of the COVID-19 lockdown (from March to June 2020). The analysis draws on forty-seven semi-structured interviews carried out by telephone with different migrant groups documented earlier.

The collection of interviews draws from a collaboration between the University of Milan (UNIMI) and the association TodoCambia. UNIMI researchers trained the volunteers of the association to conduct semi-structured qualitative interviews with the initial aim of understanding the changed life conditions of those migrants who,

3 Here, most of these changes were largely reverted by law no. 173/2020. 
during the lockdown, had been excluded from the main activities of the association (Italian school and legal helpdesk support) that had been interrupted or carried out remotely due to the pandemic. An initial sampling of fifteen interviews was carried out with migrants that belonged to the associational network and was then followed by a snowball sampling procedure. We followed the guidelines of ethical principles to ensure our informants' anonymity. Thus, we have anonymized the names of the research participants.

The interview guidelines revolved around the following macro themes: legal history, employment, and future expectations post-COVID-19, self-help, and support networks. Interviews lasted between 30 and 50 minutes and were carried out in both Italian and English. All the interviews were recorded on audio.

The main sample characteristics are as follows. Concerning gender, thirty-three interviews were carried out with females and fourteen with males. The majority of the participants were of working age, between age 28 and 63. Interviewees were from the following countries: Ecuador (6), Colombia (4), Tunisia (1), Egypt (2), Peru (13), Nigeria (1), Mali (1), El Salvador (5), Uruguay (1), Russia (1), Ghana (1), Albania (3), Turkey (1), Ukraine (1), Sri Lanka (1), Romania (3), Cameroon (1), and Brazil (1). Interviewees worked as private tutors or babysitters, in the fashion industry, as interpreters and cultural mediators, as qualified nurse assistants, in the cleaning and hospitality sector, as social workers in the Third Sector, or as care and domestic workers in private homes, while eight interviewees were unemployed.

Concerning the legal status of interviewees, ten were naturalized citizens, seventeen were long-term residence permit holders, fourteen were holders of temporary residence permits, one was undocumented, and five did not want to share their status.

Here, content analysis was used to present the qualitative results. This analysis helped the researchers in grouping, comparing, and examining the findings of the study.

\section{LEGAL (IN)SECURITY IN THE TIME OF PANDEMIC}

\section{Suspended (II)legalities}

The pandemic had a different impact on naturalized citizens and SLP-holders on the one hand and temporary permit holders and undocumented migrants on the other hand. Naturalized citizens and SLP-holders did not engage significantly with Italian bureaucracies, except for the renewal of personal documents such as passports.

We have all taken Italian citizenship, and at least we do not have to worry about going to the police headquarters. (Flor, Peru, naturalized citizen)

From the point of view of documents, we are okay. My children are Italian citizens, and so is my husband. I have a long-term residence permit, but I have not yet been 
able to apply for citizenship. I had to renew my Peruvian passport when the COVID-19 emergency began. The Peruvian consulate in Milan suggested that I do not come to their offices unless it is something urgent [...]. (Ana, Peru, SLP-holder)

While the lack of passports might have had little effect in practice (as international mobility opportunities have been significantly curtailed for all), the uncertainty regarding the time needed to have passports renewed could, in any case, represent a relevant source of anxiety. "I have an unlimited residence card; all I need is a passport. I'm worried that if something happens back home to our loved ones, we won't be able to visit them" (Drita, Albania, SLP-holder).

As shown by the words of Drita, lack of a passport could represent a relevant obstacle in the case of an emergency or transnational care crisis demanding a migrant's immediate presence at home. This uncertainty also applies to the release of family permit of stay and consequent reunification, as family reunification paths are on hold; cases were reported of people obtaining a family visa but unable to enter Italy because inbound flights were canceled or blocked from entering, resulting in their visa expiration.

Migrants entitled to a short-term permit of stay subject to periodic renewals (such as students, economic migrants, family migrants, or asylum-seekers) had, instead, been the worst off during the crisis.

The pandemic affected or blocked many migrants from achieving more stable legal career goals (such as pursuing long-term residency and naturalization).

I have a permanent residence permit. I asked for citizenship three years ago, but I don't know when I'll get it, and with this situation, it'll be even worse, maybe in 5 years, they'll give it to me. (Erika, Peru, SLP-holder)

I had applied for a long-term permit, but unfortunately, I needed housing eligibility. My permit expired in November [2019]. I applied for a renewal and had my appointment in April, but they sent me two postponement messages until August. I'm now waiting for my housing certificate. (Gisell, El Salvador, expired short-term permit)

This block in pursuing more stable legal careers is due to the curtailed activity of public administrations such as immigration offices (in charge of receiving and processing the application), municipalities (in charge of providing relevant documentation, such as residency or housing certificates), or INPS - National Social Insurance Agency - (as regards proof of employment and tax contributions) that are currently generating extended backlogs.

The postponement of legal stabilization procedures can, however, represent a relevant source of risk in the time of the pandemic. Many migrants are worried about their economic prospects and fear that the deepening economic crisis could jeopardize the maintenance of economic and housing proofs over time. In turn, the 
postponement of legal stabilization might endanger professional advancement (Anderson 2010a), as well explained by Liz:

I had all the requirements to apply for Italian citizenship [. . .], but I now find myself still having to renew my residency permit. I had my renewal appointment on the day of the total closure. I'm waiting for another appointment. In the hospital where I work, I've a temporary contract like other foreign colleagues. After almost ten years of work, we'd like to have the opportunity to have a stable job in public health care, but we can't because we don't have Italian citizenship. We do have the requirements to be Italian citizens, but the problem is the lengthy procedure. (Liz, Peru, expired short-term permit)

Temporal control is shaped by migration systems that require migrants to wait and put their lives on hold, thus leaving the future uncertain.

After ten years of residence in Italy, I was granted citizenship. But many people are terrified by the situation for their residence permits. For now, everything has stopped, but at the same time, everything continues as it was before. I'm worried that when the emergency will be over, people won't have the possibility to maintain their legal position, and that, because of this bureaucratic machine, a large portion of immigrant workers may become irregular or fall into the hands of the recruiters of (irregular) day laborers. (Jose, Colombia, naturalized citizen)

As well explained by Jose, many migrants are likely to face a precarious legal situation due to the ongoing effects of the pandemic that affects their employment status. The fear is that the pandemic will push migrants into irregularity as a consequence of unemployment, as many of them will be unable to renew their work permits, which is premised on having a regular job.

The temporal extension of the uncertain legal conditions had ambivalent and somewhat paradoxical effects on a specific category of legally-precarious migrants, that is, asylum-seekers with a (self-perceived) limited chance of obtaining protection. Several interviewees reported that suspended application processing by the Territorial Commissions has somewhat provided advantages to the asylum-seekers pending other options, as illustrated in the following excerpt.

I've applied for political asylum because in my country I had some problems. They gave me a permit of stay for asylum, but it's a temporary one, and now it has been extended because my commission was in February; they extended it to June, and now I think it'll go after September. I don't think they'll give me political asylum. They closed a lot of places; they changed the commission date. [...] Actually, for me, it's a good thing because I thought that if they tell me no, at least it'll extend my time, it'll buy me time to wait for maybe an amnesty, and so I can be okay. (Leo, Peru, asylum-seeker) 
The words of Leo show that the condition of uncertainty increased by the pandemic can paradoxically give people hope to act and long for better future outcomes, getting extra time to strategize, to prepare for the eventual asylum application outcome soliciting for legal support, or wait for more favorable opportunities, such as amnesty. Thus, waiting is not just passive but can also be an active process as people tend to engage in a wide array of activities that are both present-focused and future-focused (Rotter 2016: 82).

\section{Suspended Welfare Access}

The temporary suspension of legal identities has jeopardized access to key social rights that acquired critical relevance during the pandemic; this includes, for instance, getting access to the medical treatments guaranteed by one's health card (whose length is tied to the residence permit ${ }^{4}$ ) or to the social rights that require a valid ID card, certifying ones' municipal registration (municipal registration should also be renewed every time one's residence permit expires).

At the moment, I'm without a valid residence permit. I only have the receipt [the postal receipt obtained when the request for a residence permit issuance or renewal is put forward, n.d.a.] but with the receipt, I can't ask for bonuses because, e.g., I know that my municipality issues bonuses to mothers with kids, but you need to have your [...] how is it called? A valid residence permit, but also the ID residence card. (Luisa, Peru, expired family reunification permit)

I know there's some kind of public relief support. I saw that there's a notice, but they want ISEE. But I don't have the ISEE since I don't have a valid ID residence card. (Adu, Ghana, short-term permit)

As the case of Adu clearly shows, the lack of ISEE (Indicatore della situazione economica equivalente, that is, equivalent economic status indicator) hampers access to means-tested benefits. As several migrants work in the shadow economy with no contract or official documentation as a consequence of their undocumented or legally-precarious status, the exclusion from ordinary employment-based allowances (such as Naspi or Cassa Integrazione - unemployment benefit) or those extraordinarily introduced as a response to the COVID-19 emergency (the so-called ristori) is also an issue of concern.

$4 \quad$ While in Italy undocumented migrants have access to urgent healthcare provisions, they might be asked to pay for non-urgent treatments. 
I heard that the state is providing help to those who are self-employed, but those are people with a work contract that are not working [because of the pandemic]. Those working in industries have entered the cassa integrazione, then there'll be those people who work in the shadow market. They can't receive any salary; the state is not helping those who are more in need. In my opinion [...] Italians would complain so much, as they don't agree with helping informal workers. (Pablo, Peru, short-term permit)

The suspension (or virtualization) of many face-to-face public administration activities during the pandemic has also contributed to an abrupt increase in the relevance of digital services, websites, and platforms (e.g., electronic medical prescriptions, online applications for unemployment benefits or subsidies, etc.) to obtain information and/or to submit applications. According to some interviewees, this has further complicated welfare access.

We had some problems with the health card because, since it's tied to the expired residence permit, and when we went to the doctor for a prescription, there was a conflict with the system, so we couldn't get it. [...] My wife is also trying to apply for the unemployment benefit, but we can't submit the application through the INPS website; the system doesn't accept her application, as her residence permit has expired. (Alejandro, Colombia, family reunification permit holder)

Regardless of one's legal status, knowledge of how the system works is also important. Interviewees show a relevant degree of uncertainty regarding the newly introduced COVID-related support packages - that is, which kind of benefits have been introduced, to which categories they are entitled, how to apply, and to whom they should go for information and support. While new forms of support were introduced, as documented in section two, institutional and bureaucratic barriers have increasingly limited migrants' concrete access to these welfare support packages. Here, those with limited knowledge of the language and/or institutional context (let alone digital means of connection and competences) were those who were most seriously affected.

I don't know where to turn to for receiving support. I heard that there could be some help from the state, some bonuses, but I don't know much about it. (Diego, Peru, naturalized citizen)

Yes, I've heard about it, but I don't know if we, as migrants, can apply. The only help I know there is, e.g., Caritas that offers food or our neighborhood church that is active in providing food every fortnight to the neediest families. (Saadia, El Salvador, asylum-seeker) 
As shown by the words of Saadia, the institutional barriers to public support are somehow compensated by caritative support provided by non-state actors, including both well-established, religious-affiliated institutions (such as Caritas or churches) and newly-established informal solidarity groups that have increasingly provided relief in many cities, as a response to the growing situation of crisis, somehow de-bureaucratizing public support.

\section{CONCLUDING REMARKS}

We documented how temporal and precarious legal conditions embedded in the Italian migration system have interacted with the COVID-19 crisis especially affecting migrants with temporary and undocumented status. In particular, the study showed that legal precariousness is deeply rooted in - and constantly reproduced by - the Italian immigration system, treating migrants as a temporary phenomenon and making long-term and secure status especially difficult to achieve and maintain.

For those unable to renew their status, the pandemic has triggered a prolonged suspension of one's legal status, with significant spill-over effects on several aspects of one's personal and familial life.

The suspended legality has jeopardized family reunification projects as well as naturalization and access to long-term residency. The curtailed opportunities for cross-border mobility have also represented a major source of anxiety to those migrants that have suddenly found themselves spatially trapped and unable to respond to a possible transnational family crisis. While for some asylum seekers, this suspension might have provided more time to strategize and/or to wait for a more favorable window of opportunity, for most legally precarious migrants, the possible effects of the recent pandemic meant an indefinitely prolonged risky uncertainty. The fear is that of possibly relapsing into undocumentation due to the worsening economic scenario as it is tied to one's employment status or that of nullifying one's efforts to achieve greater legal stability or to start over from the very beginning.

The pandemic has also made access to healthcare and financial relief more urgent; however, access to state-provided resources might be seriously jeopardized by combining legal precariousness and inaccessibility to bureaucratized rights. On the one hand, several migrants were unable to provide the proof they needed to access means-tested benefits; on the other hand, those working informally could not access employment-based measures.

Having a secure legal status, such as citizenship or a long-term permit, does not automatically lead to access to welfare as it is dependent on one's employment and financial condition. While migrants with temporal and precarious status are the worsthit, those with secure status have also found it difficult to access welfare, including the financial relief support provided by the national, regional, and local governments. 
Accessing rights in the time of pandemic is jeopardized by the lack of reliable information. The messages issued during the pandemic were especially difficult to decode for those who had limited knowledge of the national bureaucratic language and the local institutional landscape. The virtualization of several services made those less equipped with technological skills somehow excluded, also considering that all major intermediary services were offering support only by phone or had their services severely curtailed.

The temporal uncertainty that migrants experience stems from the impossibility of obtaining thorough knowledge of current conditions in the host community and the feeling of a highly unpredictable future (Williams, Baláž 2015). Only time will tell what the real extent of the impact of the crisis triggered by the pandemic will be, particularly in terms of relapse into undocumentation, prolonged precarity, and lost opportunities of individual and familial integration and advancement.

\section{REFERENCES}

Anderson, Bridget (2010a). Migration, Immigration Controls and the Fashioning of Precarious Workers. Work, Employment and Society 24/2, 300-317.

Anderson, Bridget (2010b). Mobilizing Migrants, Making Citizens: Migrant Domestic Workers as Political Agents. Ethnic and Racial Studies 33/1, 60-74.

Baas, Michiel, Yeoh, Brenda SA (2019). Introduction: Migration Studies and Critical Temporalities. Current Sociology 67/2, 161-168.

Banki, Susan (2013). Precarity of Place: A Complement to the Growing Precariat Literature. Global Discourse 3/3-4, 450-463.

Bonizzoni, Paola (2020). The Border(s) Within: Formal and Informal Processes of Status Production, Negotiation and Contestation in a Migratory Context. Migration, Borders and Citizenship. Migration, Diasporas and Citizenship (eds. Maurizio Ambrosini, Maurizio, Manlio Cinalli, David Jacobson). Palgrave Macmillan, Cham, 217-235.

Calavita, Kitty (2005). Immigrants at the Margins: Law, Race, and Exclusion in Southern Europe. Cambridge University Press.

Cwerner, Saulo B (2001). The Times of Migration. Journal of Ethnic and Migration Studies 27/1, 7-36.

Cwerner, Saulo B (2004). Faster, Faster and faster: The Time Politics of Asylum in the UK. Time \& Society 13/1, 71-88.

Da Lomba, Sylvie (2010). Legal Status and Refugee Integration: A UK Perspective. Journal of Refugee Studies 23/4, 415-436.

Dell'Olio, Fiorella (2004). Immigration and Immigrant Policy in Italy and the UK: Is Housing Policy a Barrier to a Common Approach Towards Immigration in the EU? Journal of Ethnic \& Migration Studies 30/1, 107-128. 
Devillanova, Carlo, Colombo, Cinzia, Garofolo, Primo, Spada, Anna (2020). Health Care for Undocumented Immigrants During the Early Phase of the Covid-19 Pandemic in Lombardy, Italy. The European Journal of Public Health 30/6, 1186-1188.

Dotsey, Senyo, Lumley Sapanski, Audrey (2021). Temporality, Refugees, and Housing: The Effects of Temporary Assistance on Refugee Housing Outcomes in Italy. Cities $111,103100$.

Dotsey, Senyo (2018). International Migration and Livelihood Dynamics During the Recent Economic Crisis: A Study of Ghanaian Migrants in the Como Province, Italy. Migration and Development 7/1, 104-123.

Ferraris, Valeria (2008). L'obbligata Illegalità: L'impervio Cammino Verso un Permesso di Soggiorno. Studi sulla questione criminale 3/3, 25-44.

Gargiulo, Enrico (2017). The Limits of Local Citizenship: Administrative Borders within the Italian Municipalities. Citizenship Studies 21/3, 327-343.

Guadagno, Lorenzo (2020). Migrants and the COVID-19 pandemic: An initial analysis. IOM.

Hartley, Lisa, Fleay, Caroline, Tye, Marian E (2017). Exploring Physical Activity Engagement and Barriers for Asylum Seekers in Australia Coping with Prolonged Uncertainty and no Right to Work. Health \& Social Care in the Community 25/3, 1190-1198.

Rotter, Rebecca (2016). Waiting in the Asylum Determination Process: Just an Empty Interlude? Time \& Society 25/1, 80-101.

Simmelink, Jennifer (2011). Temporary Citizens: U.S. Immigration Law and Liberian Refugees. Journal of Immigrant \& Refugee Studies 9/4, 327-344.

Standing, Guy (2011). The Precariat: The New Dangerous Class. Bloomsbury.

Veugelers, John WP (1994). Recent Immigration Politics in Italy: A Short Story. West European Politics 17/2, 33-49.

Williams, Allan M, Baláž, Vladimír (2015). Migration, Risk and Uncertainty. Routledge. 


\section{POVZETEK}

\section{MIGRACIJE IN PRAVNA NEGOTOVOST MED PANDEMIJO: KVALITATIVNA ŠTUDIJA ITALIJANSKEGA PRIMERA Paola BONIZZONI, Senyo DOTSEY}

Študija raziskuje, kako pravna negotovost, vgrajena $v$ italijansko priseljensko politiko, med pandemijo Covida-19 vpliva na življenje migrantov. Pravni status namreč močno zaznamuje vse vidike njihovega življenja in pomembno vpliva tudi na njihovo integracijo.

Raziskovalca sta s kvalitativno metodo analizirala empirične podatke, zbrane s sedeminštiridesetimi polstrukturiranimi intervjuji (med marcem in junijem 2020) z različnimi skupinami migrantov $-z$ begunci, s prosilci za azil, z ilegalnimi migranti ter s humanitarnimi, ekonomskimi in naturaliziranimi migranti, ki v Italiji živijo od nekaj mesecev do več desetletij.

Pandemija ni povzročila samo zaprtja mednarodnih meja, ampak tudi virtualizacijo administrativnih služb in vladnih agencij, ki obravnavajo prošnje in izdajajo dovoljenja za bivanje in delo oziroma se ukvarjajo s postopki naturalizacije tujih državljanov. Učinki dolgotrajne negotovosti, liminalnosti in čakanja pomembno vplivajo na udeležbo migrantov v socioekonomskih dejavnostih.

Ugotovitve študije kažejo, da omenjeni procesi negativno vplivajo na življenja migrantov in ogrožajo združevanje družin, naturalizacijo, dostop do dovoljenj za neomejen čas bivanja in socialnega skrbstva ter večje socialne stabilnosti. Vse to otežuje načrtovanje novih migracijskih postopkov oziroma celo njihovo regresijo.

Avtorja ugotavljata, da je pravna negotovost v italijanski priseljenski politiki globoko zakoreninjena in migrante obravnavani kot začasni pojav, kar onemogoča pridobitev in vzdrževanje dolgoročnega in varnega pravnega statusa. V Italiji so tudi legalni migranti v nevarnosti, da zdrsnejo v ilegalo - njihov legalni status je namreč povezan z zaposlitvijo, ki pa je zaradi slabšanja gospodarskih razmer vedno bolj ogrožena. Pravna negotovost negativno vpliva tudi na druga področja življenja migrantov.

Pandemija je otežila tako dostop do zdravstvenih storitev kot do paketov denarne pomoči; dostop do sredstev, ki jih zagotovlja država, je odvisen od kombinacije pravne negotovosti in nedostopnosti zbirokratiziranih pravic. V Italiji je uveljavljanje pravic med pandemijo ogroženo predvsem zaradi pomanjkanja verodostojnih informacij in virtualizacije številnih služb.

Čeprav so najbolj na udaru migranti z začasnim oziroma negotovim pravnim statusom, je dostop do različnih pravic tako na državni, pokrajinski in lokalni ravni otežen tudi migrantom z urejenim pravnim statusom.

Čeprav razsežnosti vpliva pandemije še niso natančno ocenjene, ugotovitve študije kažejo, da so različne skupine migrantov izpostavljene dolgotrajni pravni negotovosti, kar vpliva na druge vidike njihovih življenj, vključno s socioekonomsko vključenostjo. 